\title{
A Librarian's Participation in the Conference on the African University and National Educational Development
}

\begin{abstract}
The author reports upon his role in a recent conference on African higher education held at Lake Mohonk, New York. He operated a reference library there and describes the uses that were made of it by the delegations. He participated in discussions, served as reporter for selected sessions, and encouraged the adoption by the conference of a strong statement in support of libraries which became "the only conclusive recommendation formally accepted by" it!

There are comments upon the implications of future participation of librarians in such conferences.
\end{abstract}

W HEN KaRL W. Bigelow, who serves in the dual capacity of executive officer of the Institute for Education in Africa at Teachers College (Columbia University) and executive officer of the AfroAnglo-American Program in Teacher Education, announced that he was responsible for organizing an international conference to explore the problems of teacher education primarily in the English-speaking sections of Africa, the author called to his attention the merit of considering the role of the library in the educational structure. In educational planning, it was pointed out, the library all too frequently is treated as a peripheral appendage to the educational process. Educators thereby fail to make use of an important tool which could help them achieve their own goals. Fur-

Dr. Forman is Professor of Education and Librarian at Teachers College, Columbia University. thermore, of course, the library is central to the work of universities and colleges. In due course, the author received a formal invitation to attend the Conference on the African University and National Educational Development at Lake Mohonk, New York, September 8-18, sponsored by the organizations with which Professor Bigelow is associated.

The conference brought together personalities representing academic institutions, foundations, and governmental agencies from the United States, Great Britain, and thirteen countries of Africa in which English is used as a medium of instruction. The delegations examined the problems of education by listening to panel discussions and to papers read by experts and by exchanging experience and comment. There was no intent to arrive at recommendations and decisions. It was the purpose of the conference to reproduce papers and recorded discussions in a conference document which 
would form the basis for a book and, it is hoped, to serve the interests and informational needs of those concerned with this most important subject. The conference organizers also felt that the meeting of delegates, the establishment of personal contacts, and the exchange of information and opinion would be of sufficient value to merit the energies and resources expended to make the meeting possible. The main American educational group present represented Teachers College; the main British representation came from the University of London; the African delegation represented people from universities, institutes of education, teacher training institutions, and ministries of education.

Teachers College library supported the conference by establishing a small reference library at Lake Mohonk. The reference library project was begun by compiling a bibliographical list. This was undertaken by Wayne Gossage. Titles were selected with an eye toward bringing together a collection for exhibit, reference, and use by the conference participants. The list was fairly representative of the Teachers College collection of books and periodical materials on African higher education. An atlas, dictionaries, biographical dictionaries, encyclopedias, and other general references were included. The bibliography served as a guide to the selection of materials for the conference library, and it was published as part of the conference document.

The library materials were arranged in an attractive room in a fairly central position at the hotel, with hand-lettered signs to describe their purpose. The attention of the conference delegates was called to the collection by an information bulletin. The library attendant designated to look after the collection was a Teachers College library page, Master Philip Forman, aged fourteen and onehalf. He, however, was called away for clerical duties at Lake Mohonk, and the collection was left largely unattended. Nevertheless, the borrowers' cards show that active use was made of the collection. The borrowed items were easily categorized as: (1) directly related to subjects under discussion; (2) publications which were mentioned at conference discussion; or (3) publications associated with personalities at the conference. Some patrons reported that they could not find the books, articles, or references for which they were looking.

The library served other useful purposes. One delegate from Nigeria reported that he examined the collection to identify categories of materials important for the library of the institution he represented and that examination of the collection would enable him to make recommendations to his librarian. Some of the delegates deposited relevant documents in the library for use by delegates from other countries. After the close of the conference these documents were added to the Teachers College library.

There were many other experiences at Lake Mohonk which had bearing on librarianship. For example, useful personal relationships were established with representatives of a variety of African nations and institutions. A chief education officer from one African country offered to supply Teachers College library with full documentation dealing with the development of education in his country.

Of particular importance were the personal relationships established with fellow faculty members present. Surely as an outcome of living together, the formal communication and telephone calls of the past will take on a new warmth and a new meaning.

The presence of a librarian also evoked many questions as to libraries. One was the present status of computerization and information retrieval; another dealt with 
plans for setting up bookmobiles; a third dealt with the philosophy behind openshelf collections and the percentage of allowable losses. It must be kept in mind that a librarian was not a conference delegate in any special capacity but simply as one among equals to bring to bear his experience and training on the subjects under discussion. He was also involved in the administrative mechanics of the conference, as were others, as a rapporteur; his duties required that he attend designated group meetings, record the discussions, and submit them for typing and eventual incorporation into the conference document.

At the conference the papers read, and particularly the varied experiences represented by the conference delegates, led to a consideration of many facets of the central problem of the conference. Papers were read dealing with preservice and in-service education of teachers, the advanced training of educational specialists, the expansion of educational research and experimentation, and cooperative procedures designed to facilitate advance along these lines. But no matter what the subject under discussion, the delegates spoke-again and again-of the pressing need for the dissemination of research, the need for sharing ideas and information. This concept was an important one in a major paper read by John Lewis, professor of education and head of the department of education in tropical areas at the University of London. Professor Lewis opened his discussion of "Educational Research and National Development" with the statement that "... provision must be made for the immediate and continuing application of the research findings to the development of education. ..." A. G. Joselin, head of the department of education at Ahmadu Bello University in Northern Nigeria, touched on the same theme when he dealt with the need for university institutes of education "to develop and main- tain a professional library service available to all teachers in the institute's area." Other conference participants also spoke of the pressing need for the publication and distribution of reports, abstracts, and bibliographical guides. The question of dissemination of research findings, although not initially treated as a major subject of discussion for the conference, became central in the deliberation of many of the discussion groups. One of the groups recorded the proposal "that the conference go on record as recommending that there be established various types of libraries, information centers, educational materials centers, documentation centers or clearing houses-national, regional or international-with archival and distributive functions, dealing with education in Africa. Such institutions should minimize duplication of efforts and make known research projects and their findings, collect and distribute the reports of governments and other interested agencies as well as all types of bibliographical information." This was incorporated in the group report and at the final session was presented for consideration of the entire delegation. This proposal became the only conclusive recommendation formally accepted by the conference.

Experience at the conference, the deliberations of the delegates, and the resultant conference document strongly support several implications for librarianship as well as for organizers of future similarly structured conferences.

1. A librarian should have been involved in conference planning.

2. A librarian capable of providing information services should have been available during the hours when the conference library was open. Such a service might have contributed to an even higher level of discussion.

3. The role of the library in national ed-

(Continued on page 69) 
As for the first of these, this reviewer is frankly skeptical. After seven hours of lowlevel communication in one of the 123 discussion groups, he voted vehemently against all recommendations requiring further communication among librarians or between them and others. Perhaps his was an atypical group, or perhaps he is a misanthrope; other participants reported more fruitful experiences. As for the publicity objective, it is possible that the CWC contributed something to the national library legislative victories which followed within six months. Its success, however, will rest ultimately upon substantive results directly related to the student use problem. The ten major recommendations coming out of the conference have been referred into the ALA structure, and President Wagman reported recently that "many are well on the way to implementation." So far the most tangible result is another conference, scheduled for March 1965, with representatives of other national organizations.-Clifton Brock, University of North Carolina.

\section{PROFESSIONAL DUTIES}

(Continued from page 39 )

or Clerical?" Library Journal, LXXXVI (September 1, 1961), 2758-59. Used one hundred professional and clerical duties selected from ALA List to check actual practices in twenty-one public libraries.

Houlridge, D. L. "Division of Staff: A Canadian Example," Assistant Librarian, LVII (October 1958), 201-203. List of duties drawn from Toronto public library practices.

Library Association. Professional and Nonprofessional Duties in Libraries. London: The Association, 1962. 77p. Descriptive list, arranged under twelve major headings, each divided by professional and nonprofessional classification.

Lochhead, D. G. "I Am a University Librarian," Canadian Library Association Bulletin, XIII (December 1956), 100-105. Description of a "typical" day in the life of a university librarian, showing how his time is spent.

London. Northwestern Polytechnic School of Librarianship. Professional Work for Professional Librarians. London: The
School, August 1958. 10p. (Occasional Paper, No. 12). Discussion by two British librarians, one of duties in government, the other in public libraries.

McAnally, Arthur. "Privileges and Obligations of Academic Status," CRL, XXIV (March 1963), 102-108. Discusses composition of staff.

McNeal, Archie L. "Ratio of Professional to Clerical Staff," CRL, XVII (May 1956), 219-23.

Skilling, B. C. "Restrictive Practices," Assistant Librarian, L (December 1957), 222-23. Author urges that professional librarians restrict themselves to professional tasks.

Smith, Eleanor T. "What's in a Name?the Reference Librarian." NCLA, Odds and Book Ends, No. 36 (Fall 1960), 101. Analysis of work of reference librarian in a public library.

U.S. Civil Service Commission, Personnel Classification Division Librarian Series GS-1410. Washington, D.C.: Govt. Print. Off., 1957. 35p.

Wight, E. A. "Separation of professional and nonprofessional work in public libraries," California Librarian, XIV (September-December 1952), 29-32, 54, 107 16. Discusses methods of differentiating between professional and nonprofessional duties.

Wilkinson, John. "A Division of Labor," Ontario Library Review, XLI (May 1957), 87-88. General discussion of desirability of separating clerical from professional functions on staff.

Williams, Edwin E. "Who Does What: Unprofessional Personnel Problems," CRL, VI (September 1945), 301-10.

\section{AFRICAN UNIVERSITY}

(Continued from page 51)

ucational development should have been one of the subjects for discussion at this conference.

4. The development of educational programs in Africa requires the establishment of a network of supporting regional, national, and international libraries to provide the necessary information services dealing with the problems of African education. 